\title{
Structural capital, innovation capability, and company performance in technology-based colombian firms
}

\section{Capital estructural, capacidad de innovación, y rendimiento empresarial en empresas colombianas de base tecnológica}

\author{
Nekane Aramburu ${ }^{1}$ \\ Josune SÁenz \\ Carlos E. Blanco ${ }^{2}$ \\ University of Deusto (Spain) \\ KM-INOVA (Colombia)
}

Recibido el 31 de mayo de 2013, aceptado el 17 de septiembre de 2014

$\mathrm{N}^{\mathrm{o}}$ de clasificación JEL: M100

DOI: $10.5295 / \mathrm{cdg} .130427$ na

\begin{abstract}
:
In today's economy, innovation is considered to be one of the main driving forces behind business competitiveness, if not the most relevant one. Traditionally, the study of innovation has been addressed from different perspectives. Recently, literature on knowledge management and intellectual capital has provided new insights.

Considering this, the aim of this paper is to analyze the impact of different organizational conditions - i.e. "structural capital" - on innovation capability and innovation performance, from an "intellectual capital" (IC) perspective. As regards innovation capability, two dimensions are considered: new idea generation and innovation project management.
\end{abstract}

The population subject to study is made up of technology-based Colombian firms. In order to gather information about the relevant variables involved in the research, a questionnaire was designed and addressed to the CEOs of the companies making up the target population. The sample analyzed is made up of 69 companies and is large enough to carry out a statistical study based on structural equation modelling (partial least squares approach) using PLS-Graph software (Chin and Frye, 2003).

The results obtained show that structural capital explains to a great extent both the effectiveness of the new idea generation process and of innovation project management. However, the influence of each specific organizational component making up structural capital (organizational design, organizational culture, hiring and professional development policies, innovation strategy, technological capital, and external structure) varies. Moreover,

\footnotetext{
${ }^{1}$ Deusto Business School. University of Deusto. Camino de Mundaiz, 50, 20012 San Sebastián (Spain). nekane. aramburu@deusto.es; josune.saenz@deusto.es

2 KM-INOVA. Carrera 46 \# 57-36 Bogotá (Colombia). carlo_co@yahoo.com
} 
successful innovation project management is the only innovation capability dimension that exerts a significant impact on company performance.

\section{Keywords:}

Intellectual capital, structural capital, new idea generation, innovation project management, company performance, colombian firms.

\section{Resumen:}

En la economía actual, la innovación está considerada como uno de los principales factores de competitividad, si no el más relevante. Tradicionalmente, el estudio de la innovación se ha abordado desde diferentes perspectivas. Recientemente, la literatura sobre gestión del conocimiento y capital intelectual ha aportado nuevos puntos de vista.

En esta línea, el propósito de este trabajo consiste en analizar el impacto de diferentes condiciones organizativas - "capital estructural" - en la capacidad de innovación y en el desempeño de las empresas desde una perspectiva de "capital intelectual" (CI). En lo que a la capacidad de innovación se refiere, se considerarán dos dimensiones de ésta: la generación de nuevas ideas y la gestión de proyectos de innovación.

La población objeto de estudio está constituida por empresas colombianas de base tecnológica. Con el propósito de recopilar información sobre las variables consideradas en la investigación, se diseñó un cuestionario que fue administrado a los directores generales de las compañías que forman parte de la población objetivo. La muestra analizada está formada por 69 empresas y es lo suficientemente grande como para llevar a cabo un análisis estadístico de modelización de ecuaciones estructurales basadas en mínimos cuadrados parciales por medio del software PLS-Graph (Chin y Frye, 2003).

Los resultados obtenidos muestran que el capital estructural explica en gran medida la efectividad del proceso de generación de nuevas ideas y de la gestión de proyectos de innovación. Sin embargo, la influencia ejercida por parte de cada componente específico del capital estructural (diseño organizativo, cultura organizativa, políticas de selección de personal y desarrollo profesional, estrategia de innovación, capital tecnológico y estructura externa) difiere. Por otra parte, la gestión eficaz de los proyectos de innovación es la única dimensión de la capacidad de innovación que ejerce una influencia significativa sobre el desempeño empresarial.

\section{Palabras clave:}

Capital intelectual, capital estructural, generación de nuevas ideas, gestión de proyectos de innovación, desempeño empresarial, empresas colombianas. 


\section{INTRODUCTION AND RESEARCH PURPOSE}

Today's economy is driven by what we could call the "innovation imperative". As Bessant and Tidd (2007) point out, the logic is very simple: if companies do not change what they offer to the world (products and services) and how they create and deliver them, they risk being overtaken by others who do. Therefore, understanding the sources of successful innovation has become one of the main challenges for academic researchers in the business world.

Since the seminal works by Nonaka (1991) and Nonaka and Takeuchi (1995), a close link has been established between innovation and knowledge creation. In other words, it is assumed that innovation involves the generation of new knowledge. As Subramaniam and Youndt point out, "It is widely accepted that an organization's capability to innovate is closely tied to its intellectual capital, or its ability to utilize its knowledge resources" (Subramaniam and Youndt, 2005, p. 450).

Moreover, innovation lies at the core of what is known as "dynamic capabilities". According to Teece $(2007,2009)$, the "dynamic capability" concept encompasses three firstlevel (i.e. simpler) capacities. The first one is the capacity to sense and shape opportunities and threats. This is the new idea generation dimension of the innovation capability. The second one is the capacity to seize opportunities. This refers to the selection of the new ideas to be addressed and to their subsequent development and fulfilment (i.e. innovation project management). The last-mentioned refers to the company's capacity to reinvent/ transform itself and not die because of unfavorable path dependencies generated by past success (i.e. change capacity).

With this in mind, the aim of this paper is to analyze the impact of different organizational enablers - i.e. "structural capital" - on the first two above-mentioned innovation capacities (new idea generation and innovation project management), from an "intellectual capital" (IC) perspective.

The structure of this paper is the following: in the first section, the purpose of the research is explained. In the second section the conceptual framework of the research is developed. In the third section, the research hypotheses are presented. In the fourth section the research method is described. In the fifth section the research findings are explained. Finally, in the sixth and last section, the main conclusions and practical implications of the research are included.

\section{CONCEPTUAL FRAMEWORK}

\subsection{Innovation, knowledge creation, and knowledge sharing}

A unique and commonly accepted definition of innovation does not exist, but most of the existing ones agree that innovation implies conceiving and implementing something new. In line with this, Thompson (1965) defined innovation as the "generation, acceptance, and implementation of new ideas, processes, products or services"; Van de Ven (1986) pointed out that innovation is intrinsically about identifying and using opportunities to create new products, services or work practices; and Martins (2000) stated that innovation is about the 
implementation of a new and possibly problem-solving idea, practice or material artefact (e.g. a product) which is regarded as new by the relevant unit of adoption and through which change is brought about.

Of course, the conception of something new implies the creation of new knowledge. In other words, innovation requires new knowledge and new combinations of knowledge (Eisenhardt and Martin, 2000). Therefore, it could be said that the capacity of an organization to innovate lies in its capacity to generate new knowledge (Nonaka and Takeuchi, 1995; Nonaka et al., 2003). This is the point of view of authors such as: Fischer (2001) - who assumes that innovation depends on the accumulation and development of a wide variety of relevant knowledge; Leiponen (2006) - who understands innovation as the generation of novel combinations from existing knowledge; Du Plessis (2007) who identifies innovation with the creation of new knowledge and ideas to facilitate new business outcomes, aimed at improving internal business processes and structures, and to create market driven products and services; Lundvall and Nielsen (2007) - who state that "innovation represents - by definition - something new and therefore adds to existing knowledge" (p. 214); and Crossan (2010) who defines innovation as "the production or adoption, assimilation, and exploitation of a value-added novelty in economic and social spheres; renewal and enlargement of products, services, and markets; development of new methods of production; and establishment of new management systems" (p.1155). Along these lines, Davila, Epstein, and Shelton (2013), consider that innovation has to do with the production of the "next new thing" (p.7).

According to Nonaka, the creation of new knowledge is closely related to the continuous interaction between tacit and explicit knowledge. Tacit knowledge is the type of knowledge which is personal, context-specific and, therefore, hard to formalize and communicate, whereas explicit or codified knowledge refers to knowledge that is transmittable in formal, systematic language (Nonaka and Takeuchi, 1995).

Nonaka et al. (2006) consider that knowledge creation involves a continuous process through which one overcomes the individual boundaries and constraints imposed by information and past learning by acquiring a new context, a new view of the world, and new knowledge. By interacting and sharing tacit and explicit knowledge with others, the individual enhances the capacity to define a situation or problem, and apply his or her knowledge so as to act and specifically solve the problem. In the case of organizational knowledge creation, this means making available and amplifying the knowledge created by individuals as well as crystallizing and connecting it with the organization's knowledge system (Nonaka and Takeuchi, 1995; Nonaka et al., 2006).

In Nonaka's view, tacit and explicit knowledge are not totally separate, but mutually complementary entities. This interaction is called "knowledge conversion", of which there are four types: from tacit to tacit (socialization); from tacit to explicit (externalization); from explicit to explicit (combination); and from explicit to tacit (internalization).

This tacit/explicit interaction is continuous and dynamic and is shaped by shifts between the different modes of knowledge conversion. This gives rise to a "knowledge creation spiral". As previously mentioned, socialization involves the conversion of tacit knowledge into more tacit knowledge. This only can be achieved by a process of experience sharing. As a result, a set of shared mental models and technical skills will be obtained. In externalization, tacit knowledge is articulated into explicit concepts, using metaphors, 
analogies, hypotheses or models. This is triggered by dialogue or collective reflection. On the other hand, combination involves systemizing concepts into a knowledge system, which implies using different bodies of explicit knowledge. Documents, meetings, conversations or computerized communication networks could be used to this end. Finally, internalization is closely related to the idea of "learning by doing", and it means embodying explicit knowledge into a tacit one. "For explicit knowledge to become tacit, it helps if the knowledge is verbalized or diagrammed into documents, manuals or oral stories" (Nonaka and Takeuchi, 1995, p. 69).

As can be noticed, in all the previously-mentioned processes knowledge sharing is involved, which means this is a critical aspect in enlarging organizational knowledge. In other words, the knowledge that the organization possesses cannot be amplified if the knowledge possessed by individuals is not shared.

Given that (as previously explained) innovation consists of an ongoing pursuit of harnessing new and unique knowledge (Subramaniam and Youndt, 2005), the study of innovation-permitting conditions involves the study of those conditions that foster the creation of new knowledge. And an organizational context which favors knowledge creation and subsequent innovation is a context which favors the exchange of ideas and experiences among people, and which encourages experimentation and continuous questioning of established patterns.

In the case of this paper, this organizational context is going to be analyzed through the lens of "intellectual capital" (IC).

\subsection{Intellectual capital}

According to Kianto (2007), IC research should address organizational capabilities for producing and mastering change through perpetual learning and innovation. In the fast-paced market environment of today and the future, it is not enough for organizations merely to provide leverage for their existing IC.

The concept of IC has been subject to many definitions, but most of them could be grouped into two categories. The first one equates the concept of IC with that of "knowledge capital". Along these lines, IC is considered to be the sum of all knowledge firms utilize for competitive advantage. This is the point of view of authors such as Nahapiet and Ghoshal (1998), Stewart (1997) and Youndt et al. (2004).

Other authors, however, view things from a broader perspective and consider IC to encompass other intangible resources and activities as well. By way of an example, the European Commission (2006) states that "Intellectual capital is the combination of the human, organizational, and relational resources and activities of an organization. It includes the knowledge, skills, experiences, and abilities of the employees; the R\&D activities, the organizational routines, procedures, systems, databases, and intellectual property rights of the company; and all resources linked to the external relationships of the firm with customers, suppliers, R\&D partners, etc.”. Authors such as Bontis (1999) and Marr (2006) are closer to this second perspective.

Whichever the perspective adopted (limited to knowledge or holistic), IC tends to be split up into different categories. Although the specific labels employed may vary, an initial distinction is generally made between human and structural capital (i.e. between thinking 
and non-thinking resources; Andriessen, 2004; Yang and Lin, 2009). A second distinction is then drawn within the latter between organizational and social capital - in the case of the knowledge perspective - and between internal and external structure - in the case of the holistic one (see Figure 1).

Figure 1

Intellectual capital categories
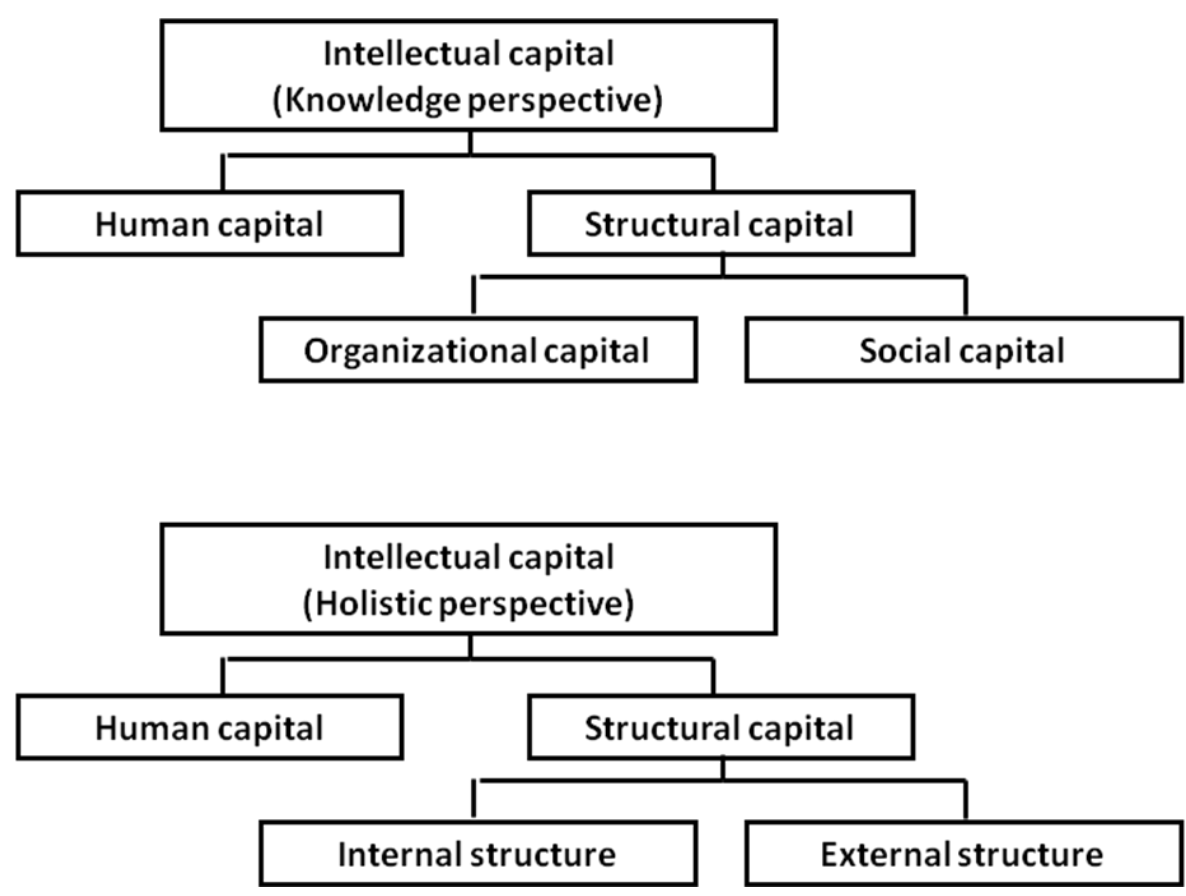

Differences between the knowledge and holistic perspective arise when it comes to conceptualizing structural capital and its two sub-components. In the case of the "knowledge perspective", the type of knowledge considered lies at the basis of the distinction made between organizational and social capital. The former refers to the institutionalized knowledge and codified experience (i.e. "explicit knowledge") residing within and utilized via databases, patents, manuals, structures, systems, and processes (Youndt et al., 2004), whereas social capital is the knowledge embedded within, available through and utilized by interactions among individuals and their networks of interrelationships (Nahapiet and Ghoshal, 1998). Of course, this second definition refers to "tacit knowledge" and it is important to note that the networks and interrelationships mentioned could be both internal and external to the firm.

In the case of the "holistic" perspective of IC, the "location" of the intangible resources and activities lies at the basis of the distinction made between internal and external structure. Along these lines, internal structure refers to the knowledge and other intangible resources 
that stay within the company when the employees have left and that derive from the organization's action processes (CIC, 2003). In other words, it encompasses the organization's essential operating processes, the way it is structured, its information flows and databases, its leadership and management style, and its culture and incentive schemes, as well as intellectual property rights (Marr, 2006). External structure refers to all resources linked to the external relationships of the firm with customers, suppliers, or R\&D partners (Meritum Project, 2002). These resources could be related to knowledge, but they could also refer to other intangible assets, such as brand image, customer satisfaction, customer loyalty, negotiating power, etc.

For the purposes of this research, the holistic perspective of IC will be adopted, as it is assumed that organizational conditions that foster innovation capability go beyond previously accumulated knowledge in different forms (i.e. databases, manuals, procedures, etc.) and encompass other intangible factors too. Hence, structural capital will be conceptualized as referring to what is left in the company when the employees have gone home (Edvinsson and Richtner, 1999; European Commission, 2006; Kianto, 2008; Kianto et al. 2010), excluding tangible resources, of course.

On the other hand, in accordance with Sveiby's classic distinction between internal and external structure (Sveiby, 1997), an additional division will be proposed for internal structure (CIC, 2003) between organizational capital and technological capital. Organizational capital (notice the difference in meaning with the knowledge perspective) refers to the set of intangibles of both an explicit and implicit, formal and informal nature, which enable company activity to be structured and developed effectively and efficiently. It encompasses elements such as organizational design, organizational culture, organizational policies and guidelines, and strategy. In contrast, technological capital (i.e. technological endowment) refers to the set of intangibles directly linked to the development of activities and functions which make up the company's technical system of operations. Within the context of this research, the Information and Communication Technologies (ICT) infrastructure will be the specific element considered in this domain.

Figure 2

\section{Structural capital architecture (holistic perspective)}

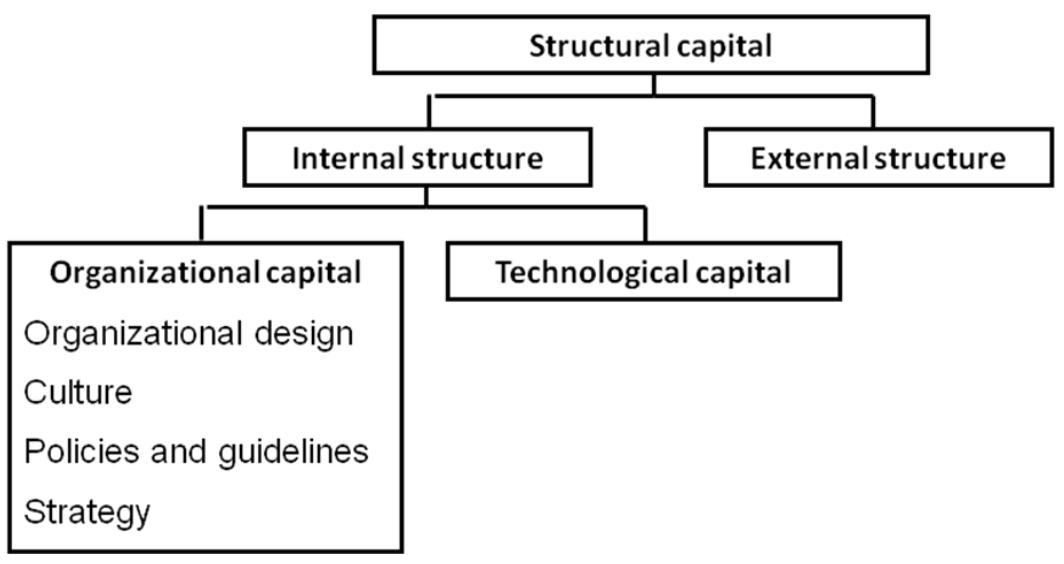


There are few studies that adopt an IC perspective when analyzing the different factors that may foster or, on the contrary, hinder the innovation capability of firms. The most comprehensive of them is the one published by Subramaniam and Youndt in 2005. In this study, Subramaniam and Youndt adopt a knowledge IC perspective and analyze the impact of human, organizational, and social capital on the incremental and radical innovation capabilities of firms.

In fact, this knowledge-focused perspective seems to be the prevalent one in empirical research. This is the case of the studies published by Brookes et al. (2007) and Menor et al. (2007) which aim at explaining product innovation performance by means of social capital and knowledge-based resources, respectively. However, Wu et al. (2007) represent an exception to this trend, as they adopt a holistic IC perspective in order to explain technological innovation performance. Another interesting survey on the relationship between intellectual capital and technological innovation is carried out by López et al. (2010). Moreover, there are also other studies that focus on the relationship between intellectual capital and other types of innovation (i.e. business model innovation, Roos and Pike, 2009).

This paper aims at analyzing the organizational conditions that foster innovation capability. For this to be done, the structural capital architecture explained previously offers a comprehensive framework for analysis.

\section{RESEARCH HYPOTHESES}

According to the conceptual framework outlined previously, research hypotheses have been developed as follows:

\subsection{Organizational capital-related hypotheses}

The first element making up organizational capital is organizational design. This refers to the type of organizational structure in place within the company, to the specific organizational units and work teams that make up this structure, to the communication channels (both vertical and horizontal) that link the aforementioned units and teams, and to the physical design of the workplace.

As regards organizational structure, Nonaka and Takeuchi (1995), and Nonaka et al. (2003) advocate the fact that certain types of structure facilitate knowledge sharing and knowledge-creation processes more than others (i.e. they are more "learning-supportive"). In particular, they defend the hypertext type of organization (a combination of hierarchy and adhocracy) as the most suitable one in order to foster knowledge sharing and creation.

On the other hand, these processes could be further supported via the existence of a specific organizational unit or group of qualified people specifically devoted to facilitating the generation and implementation of new ideas. The existence of such a unit gives formal impulse to the generation of a specific "ba" for innovation (that is, a physical or virtual space where knowledge sharing and knowledge creation takes place - Nonaka et al., 1998).

Likewise, communication channels could play a substantial role in fostering knowledge sharing and subsequent knowledge creation. As Kalla (2005) points out, knowledge sharing is a function of integrated internal communications. Although in the past knowledge flows used to be mainly vertical, from supervisor to supervisee, organizations today also 
need to foster the flow of knowledge horizontally (Dalkir, 2005). Hence, it is assumed that vertical and horizontal communication channels act as catalysts for knowledge sharing.

Physical design of the workplace is the last element making up organizational design that could promote or, on the contrary, hinder knowledge-sharing processes. According to Nonaka et al. (2001, p. 233), "The single most important factor shaping the quality of knowledge is the quality of place". This idea is related once more to the concept of "ba". Therefore, buildings and the space they embrace play a vital role in the intangible area of knowledge management (Nenonen, 2004).

In accordance with the prominent role that, from a theoretical point of view, organizational design could play in the generation of new knowledge and, hence, on innovation capability, the following hypotheses have been formulated:

H1a: Having an organizational design which favors knowledge sharing positively affects the generation of new ideas.

H1b: Having an organizational design which favors knowledge sharing positively affects innovation project management.

Organizational culture is the second element making up organizational capital. As stated earlier, an innovation-supportive culture should encourage knowledge sharing, as well as experimentation and continuous questioning of established patterns. Authors such as Allee (2003), Friedman et al. (2003), and Wiig (2004) describe the values that shape such a culture: trust, transparency, open mentality, mistakes considered as learning opportunities, support for experimentation and exploration of new territories, and cooperation and mutual help. All this gives rise to the following hypotheses:

H2a: Having an organizational culture which promotes experimentation and knowledge sharing positively affects the new idea generation process.

$H 2 b$ : Having an organizational culture which promotes experimentation and knowledge sharing positively affects innovation project management.

Organizational policies and guidelines, and more precisely, hiring and professional development policies, could play a significant role in fostering innovation capability. Innovation is a human activity and, therefore, purposefully enhancing people competences related to this domain (such as teamwork, creativity, entrepreneurship, leadership, learning, and networking capabilities) could be crucial in order to facilitate successful innovation. Thus, the following hypotheses have been formulated:

H3a: Hiring and professional development policies which try to foster knowledge sharing and innovation-related competences positively affect the generation of new ideas.

H3b: $\quad H i r i n g$ and professional development policies which try to foster knowledge sharing and innovation-related competences positively affect innovation project management. 
Strategy, and more specifically, innovation strategy, is the last component that has been considered within organizational capital for the purposes of this research. This refers to the guideline principles that indicate to an organization's members in which area knowledge creation or innovation should be pursued (Ichijo, 2007). Having a clearly established and shared innovation strategy should increase the effectiveness of the new idea generation process and the innovation project management. This gives rise to the following hypotheses:

H4a: Having an explicit and organization-wide shared innovation strategy positively affects the new idea generation process.

H4b: Having an explicit and organization-wide shared innovation strategy positively affects innovation project management.

\subsection{Technological capital related hypotheses}

Information and communication technologies can also contribute to a great extent to knowledge sharing and innovation. In particular, the existence of specific technological tools that foster the capture and storing of knowledge, as well as the connection between individuals and groups, may be very helpful (Dalkir, 2005). Therefore, the following hypotheses have been formulated:

H5a: Having ICT systems which facilitate knowledge sharing and permanent connection with different agents positively affects the new idea generation process.

H5b: Having ICT systems which facilitate knowledge sharing and permanent connection with different agents positively affects innovation project management.

\subsection{External structure-related hypotheses}

As supported by Nonaka and Takeuchi (1995), the mobilization of external knowledge held by outside stakeholders is an essential aspect in order to promote knowledge creation. In other words, the exchange of knowledge with external agents is a key element in creating new knowledge. This idea is also supported by other authors who state that "the scope and breadth of knowledge available from outside sources is generally much greater than that available from inside sources" (Maznevski and Athanassiou, 2007, p. 69). In accordance with this, the following hypotheses have been formulated:

H6a: The extent to which the company has an external innovation network positively affects the generation of new ideas.

H6b: $\quad$ The extent to which the company has an external innovation network positively affects innovation project management. 


\subsection{Company performance-related hypotheses}

Finally, the last set of hypotheses is related to the relationship between innovation capability dimensions and company performance. Although previous studies have already demonstrated the relevance of innovation as a source of superior growth and performance, they have usually done so by calculating the statistical correlation between R\&D investment and some specific measure of business growth or profitability. The aim here is to estimate the specific contribution of each innovation capability dimension to firm performance. This will provide companies with a useful insight in order to assess what to focus on in order to improve their innovation results. Thus, the following hypotheses have been formulated.

H7a: The effectiveness of the new idea generation process positively affects company performance.

H7b: Effective innovation project management positively affects company performance.

Research hypotheses are summarized in Figure 3.

Figure 3

\section{Research hypotheses}

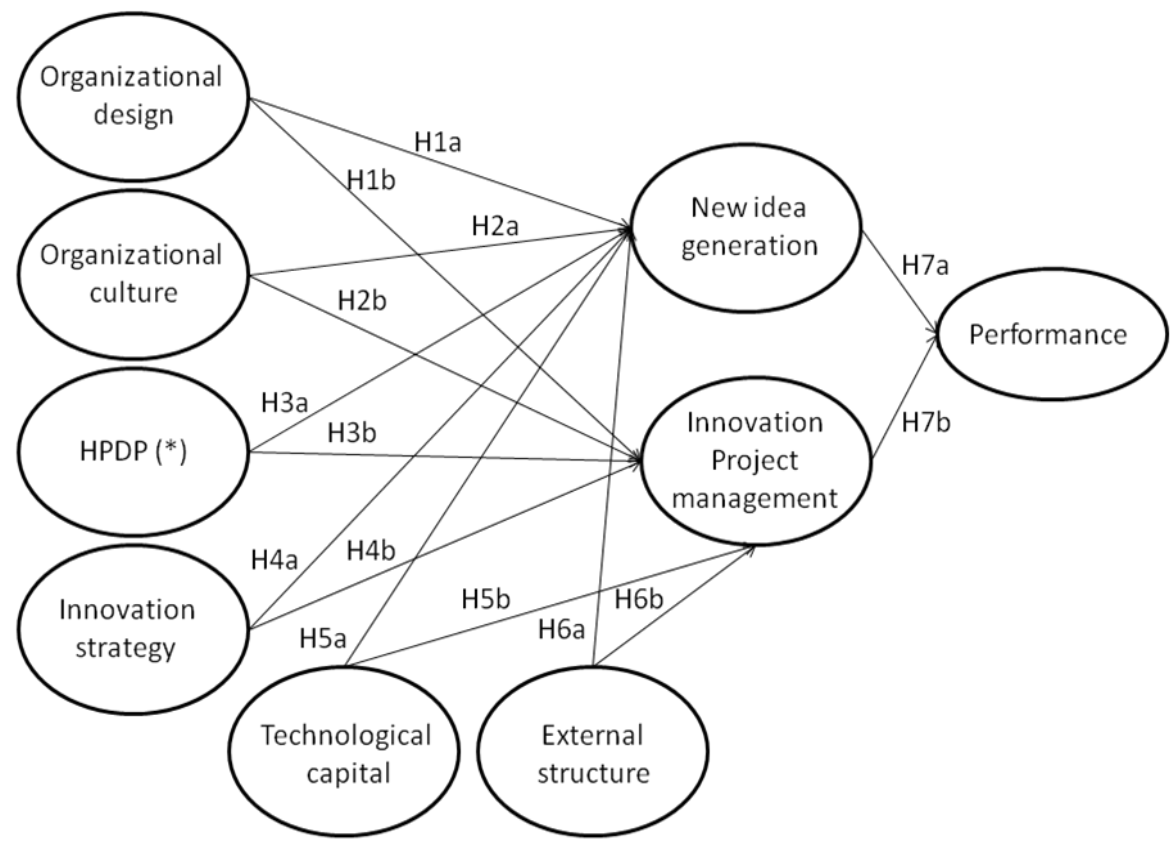

(*) HPDP: Hiring and professional development policies 


\section{RESEARCH METHOD}

The population subject to study is made up of technology-based Colombian firms. A questionnaire (see the Appendix) was administered to the CEOs of the companies making up the target population of the research. The sample obtained encompasses 69 companies and is large enough to carry out a statistical study based on structural equation modelling (partial least squares approach). The software used for the statistical analysis is PLS-Graph (Chin and Frye, 2003).

The sample is made up by firms belonging to technological industries and R\&D intensive industries, such as: Telecommunications, IT, Biotechnology, Pharmaceutical, Electronics, Research, Engineering, and Aeronautics. As in the case of Colombia there isn't any database that could enable us to ascertain the size of the entire population subject to analysis, a convenience sample was chosen.

Structural equation modelling (SEM) constitutes a second generation of multivariate analysis which combines multiple regression concerns (by examining dependency relationships) and factor analysis (by representing unobserved variables by means of multiple observed measures), in order to estimate a set of dependency relationships which are all simultaneously interrelated.

When applying SEM, two approaches can be used: the covariance-based approach and the partial least squares (PLS) approach. In the first case, the aim is to minimize the difference between the covariances of the sample and those predicted by the model. This approach is mainly used for confirmatory analysis. In the second case, however, the aim is to obtain specific values for the latent variables for predictive purposes. This approach is very useful for exploratory research in which the problems explored are complex and theoretical knowledge is scarce, as is the case in this paper (Wold, 1985).

A PLS model is analyzed and interpreted in two stages: firstly, the assessment of the reliability and validity of the measurement model and secondly, the assessment of the structural model. This sequence ensures that the constructs' measures are valid and reliable before attempting to draw conclusions regarding relationships among constructs (Barclay et al., 1995).

\section{RESEARCH FINDINGS}

Following the sequence of analysis previously described, the main findings of the multivariate analysis carried out are as follows:

As far as the measurement model evaluation is concerned, this differs depending on the nature of the construct being analyzed (reflective or formative). In the case of constructs made up of reflective indicators, individual item reliability, construct reliability, convergent validity, and discriminant validity should be ascertained. In the case of formative constructs, however, multicolinearity problems should be explored. In both cases, all the tests carried out have provided satisfactory results (see Tables 1 and 2).

In the model tested, the reflective constructs are as follows: organizational culture, hiring and professional development policies, technological capital, innovation strategy, new idea generation, innovation project management, and performance. And the formative constructs are: organizational design and external structure. Moreover, all the indicators making up the constructs have been measured using 1 to 7 Likert scales. 
Once the quality of the measurement model has been guaranteed, the quality of the structural model should then be assessed. This refers to the strength of the research hypotheses and to the amount of variance explained $\left(\mathrm{R}^{2}\right)$. In order to assess the research hypotheses, path coefficient levels should be examined, as well as their degree of significance, by means of bootstrapping techniques. Table 3 and Table 4 summarize the results obtained. These tables also show the contribution of each exogenous construct to the amount of variance explained.

The results obtained show that, in the companies studied, structural capital explains to a great extent both the effectiveness of the new idea generation process (amount of variance explained: 66.00\%) and of innovation project management (64.53\%). In particular, having an explicit and organization-wide shared innovation strategy proves to be the most relevant factor contributing to each innovation capability dimension $(23.79 \%$ and $33.22 \%$, respectively), followed by hiring and professional development policies, and external structure. Therefore, hypotheses H3a, H3b, H4a, H4b, H6a, and H6b are clearly supported.

As far as technological capital is concerned, this only exerts a significant impact on innovation project management. Thus, hypothesis H5b is supported, but hypothesis H5a is not. However, organizational design does not exert a relevant influence in any innovation capability dimension. Hence, hypothesis $\mathrm{H} 1 \mathrm{a}$ and $\mathrm{H} 1 \mathrm{~b}$ are not supported.

On the other hand, the role of organizational culture is especially noteworthy: whereas in the case of the new idea generation process having a culture that promotes experimentation and knowledge sharing does not exert a significant influence (i.e. hypothesis H2a is not supported), in the case of innovation project management it does exert a relevant, albeit negative one. Why can this be so? Why does such a culture exert a counterproductive effect?. Maybe this is due to the fact that, in the case of Colombian firms, such an organizational culture grows at the expense of efficiency to a point which is really detrimental and, as a result, innovation project management suffers.

Finally, it should be noticed that successful innovation project management is the only innovation capability dimension that exerts a significant impact on company performance. Perhaps this is due to the greater difficulties that Colombian firms may encounter in the implementation of their innovative ideas. 
Table 1

Constructs, measures, and questions - Measurement model evaluation (Part 1)

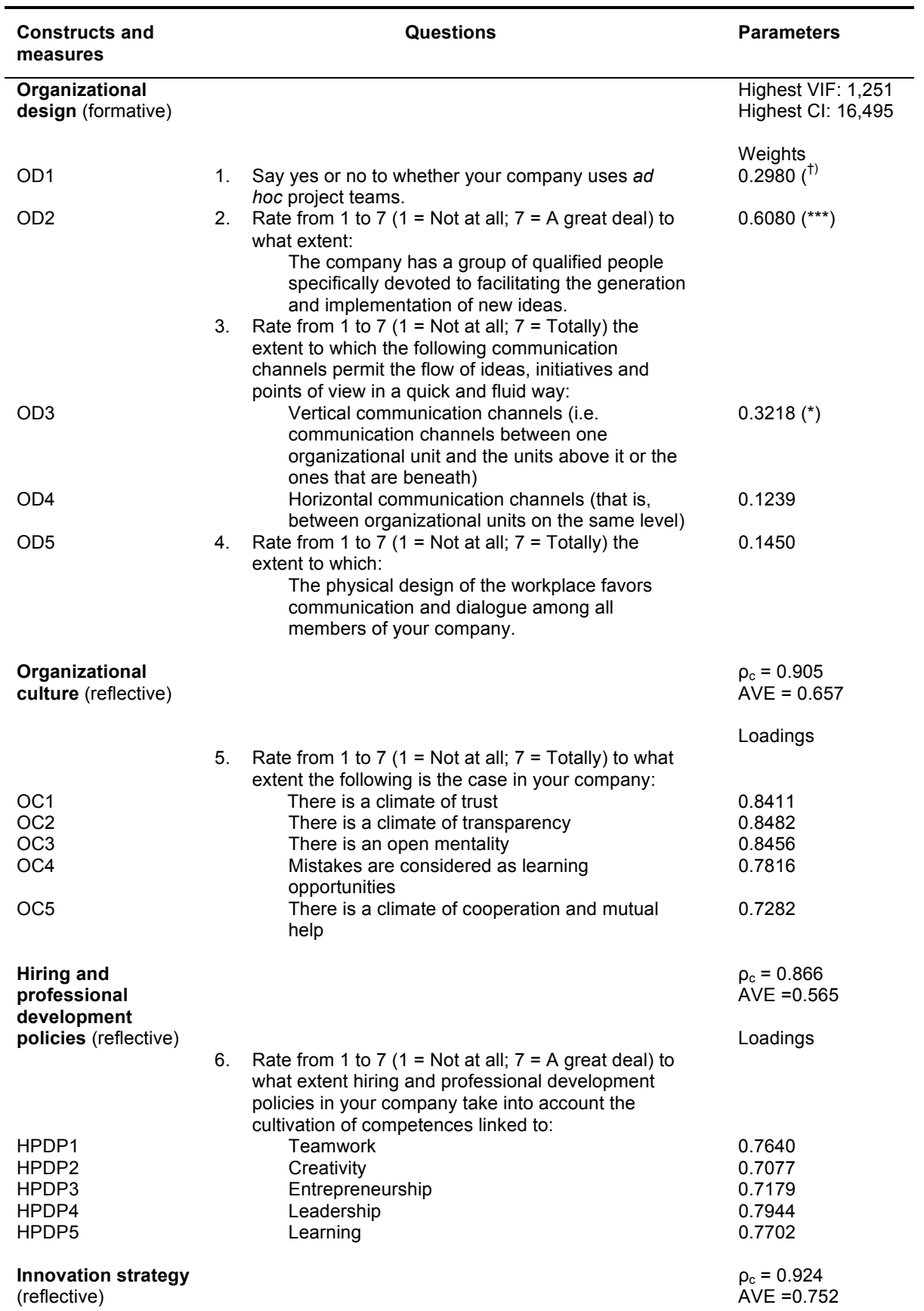




HPUP1
HPDP2
HPDP3
HPDP4
HPDP5
Innovation strategy
(reflective)
IS1
IS2
IS3
IS4
Technological
capital (reflective)
TC2
TC3

External structure (formative)

\author{
I eamwork \\ Creativity \\ Entrepreneurship \\ Leadership \\ Learning
}

7. Rate from 1 to $7(1=$ Not at all; $7=$ A great deal $)$ to what extent:

Top management carries out visible action in order to convey their commitment to innovation to the organization as a whole.

Our organization has a clearly defined innovation strategy. of the company.

The innovation strategy is consistent with the business strategy.

8. Rate from 1 to $7(1=$ Not at all; $7=$ Totally $)$ the extent to which your company is equipped with information and communication technologies specifically devised for:

The storage of organizational knowledge and its easy retrieval

Permitting permanent connection between all its members

Promoting continued action and joint work with external agents
Everybody is aware of the innovation strategy

U. 1640

0.7077

0.7179

0.7944

0.7702

$\rho_{\mathrm{c}}=0.924$

AVE $=0.752$

Loadings

0.8191

0,8871

$\rho_{\mathrm{c}}=0.874$

AVE $=0.698$

Loadings

0.8333

0.8655

Highest VIF: 2.541

Highest Cl: 13.563

Weights

9. Rate from 1 to 7 ( $1=$ No importance; $7=$ Great importance) the degree of relevance of other external agents in developing the innovation strategy of your company:

Customers

0.3436

$0.1659(-)$

or software

Other companies belonging to the same industry

ES3

ES4

ES5

ES6

Other companies belonging to different

0.0831

0.1002

industries

Universities

$1.1613\left(^{* * *}\right)$

$0.4771(-)$

$\rho_{\mathrm{c}}=0.903$

$\mathrm{AVE}=0.652$

Loadings

10. In terms of the last five years, rate from 1 to 7 the extent to which you agree or disagree with the following statements about your company ( $1=$ Totally disagree; 7 = Totally agree): 


\begin{tabular}{|c|c|c|}
\hline NIG1 & $\begin{array}{l}\text { We have identified numerous opportunities for } \\
\text { incremental improvement. }\end{array}$ & 0.7841 \\
\hline NIG2 & $\begin{array}{l}\text { We have identified numerous opportunities for } \\
\text { radical innovation, or innovation in terms of the } \\
\text { development of totally new products, processes } \\
\text { or management methods. }\end{array}$ & 0.8361 \\
\hline NIG3 & $\begin{array}{l}\text { We have identified plenty of alternative and new } \\
\text { uses for already-available technologies. }\end{array}$ & 0.7636 \\
\hline NIG4 & $\begin{array}{l}\text { The new idea generation process has been } \\
\text { managed in a conscious and effective way. }\end{array}$ & 0.8672 \\
\hline NIG5 & $\begin{array}{l}\text { We have been able to clearly distinguish which } \\
\text { of the new opportunities identified had a greater } \\
\text { potential for development. }\end{array}$ & 0.7818 \\
\hline \multirow{3}{*}{$\begin{array}{l}\text { Innovation project } \\
\text { management } \\
\text { (reflective) }\end{array}$} & & $\begin{array}{l}\rho_{c}=0.929 \\
\text { AVE }=0.685\end{array}$ \\
\hline & & Loadings \\
\hline & $\begin{array}{l}\text { 11. In terms of the last five years, rate from } 1 \text { to } 7 \text { the } \\
\text { extent to which you agree or disagree with the } \\
\text { following statements about your company }(1= \\
\text { Totally disagree; } 7=\text { Totally agree): }\end{array}$ & \\
\hline IPM1 & $\begin{array}{l}\text { We have a methodology that really facilitates } \\
\text { innovation project management. }\end{array}$ & 0.8186 \\
\hline IPM2 & $\begin{array}{l}\text { The composition of innovation project teams is } \\
\text { usually very appropriate. }\end{array}$ & 0.8087 \\
\hline IPM3 & $\begin{array}{l}\text { Each innovation project has a definite plan with } \\
\text { objectives, phases, milestones, and } \\
\text { responsibilities clearly defined. }\end{array}$ & 0.8222 \\
\hline IPM4 & $\begin{array}{l}\text { We conduct a systematic monitoring of ongoing } \\
\text { innovation projects. }\end{array}$ & 0.8439 \\
\hline IPM5 & Innovation projects are suitably coordinated. & 0.8437 \\
\hline IPM6 & $\begin{array}{l}\text { The distribution of roles in innovation projects } \\
\text { developed in cooperation has been the best it } \\
\text { could be. }\end{array}$ & 0.8264 \\
\hline \multirow{3}{*}{$\begin{array}{l}\text { Company } \\
\text { performance } \\
\text { (reflective) }\end{array}$} & & $\begin{array}{l}\rho_{c}=0.951 \\
\text { AVE }=0.866\end{array}$ \\
\hline & & Loadings \\
\hline & $\begin{array}{l}\text { 12. In terms of the last five years, rate from } 1 \text { to } 7 \text { the } \\
\text { extent to which you agree or disagree with the } \\
\text { following statements about your company }(1= \\
\text { Totally disagree; } 7=\text { Totally agree): }\end{array}$ & \\
\hline $\mathrm{CP} 1$ & $\begin{array}{l}\text { Innovation results have had a very positive } \\
\text { impact on the company's income statement. }\end{array}$ & 0.9393 \\
\hline $\mathrm{CP} 2$ & $\begin{array}{l}\text { Innovation results have had a very positive } \\
\text { impact on the company's competitive position. }\end{array}$ & 0.9623 \\
\hline CP3 & $\begin{array}{l}\text { Innovation results have allowed the company to } \\
\text { grow and improve its market share. }\end{array}$ & 0.8886 \\
\hline
\end{tabular}

Notes: $\quad \rho_{\mathrm{c}}$ : composite reliability; AVE: average variance extracted; VIF: variance inflation factor; CI: condition index; ${ }^{* * *} \mathrm{p}<0.001,{ }^{*} \mathrm{p}<0.01,{ }^{*} \mathrm{p}<0.05,{ }^{\dagger} \mathrm{p}<0.1$ (based on $\mathrm{t}_{499}$, one-tailed test). 
Table 2

Measurement model evaluation - Part II (discriminant validity)

\begin{tabular}{|c|c|c|c|c|c|c|c|c|c|}
\hline & $\begin{array}{c}\text { Hiring and } \\
\text { professional } \\
\text { develop- } \\
\text { ment } \\
\text { policies } \\
\text { (HPDP) }\end{array}$ & $\begin{array}{c}\text { Organiza- } \\
\text { tional } \\
\text { design } \\
\text { (OD) }\end{array}$ & $\begin{array}{c}\text { Organi- } \\
\text { zational } \\
\text { culture } \\
(\mathrm{OC})\end{array}$ & $\begin{array}{c}\text { Innovation } \\
\text { strategy } \\
\text { (IS) }\end{array}$ & $\begin{array}{c}\text { Technological } \\
\text { capital } \\
\text { (TC) }\end{array}$ & $\begin{array}{c}\text { External } \\
\text { structure } \\
\\
\text { (ES) }\end{array}$ & $\begin{array}{l}\text { New idea } \\
\text { generation }\end{array}$ & $\begin{array}{c}\text { Innovation } \\
\text { project } \\
\text { management } \\
\text { (IPM) }\end{array}$ & $\begin{array}{c}\text { Company } \\
\text { performance } \\
\text { (CP) }\end{array}$ \\
\hline HPDP & 0.752 & & & & & & & & \\
\hline OD & 0.565 & N.A. & & & & & & & \\
\hline $\mathrm{OC}$ & 0,571 & 0.371 & 0.811 & & & & & & \\
\hline IS & 0.471 & 0.524 & 0.584 & 0.867 & & & & & \\
\hline $\mathrm{TC}$ & 0.457 & 0.389 & 0.335 & 0.434 & 0.835 & & & & \\
\hline ES & 0,257 & 0.364 & 0.356 & 0.456 & 0.237 & N.A. & & & \\
\hline NIG & 0.607 & 0.599 & 0.587 & 0.706 & 0.453 & 0.513 & 0.807 & & \\
\hline IPM & 0.543 & 0.559 & 0.381 & 0.698 & 0.548 & 0.477 & 0.640 & 0.828 & \\
\hline $\mathrm{CP}$ & 0.491 & 0.336 & 0.376 & 0.493 & 0.412 & 0.312 & 0.566 & 0.647 & 0.931 \\
\hline
\end{tabular}

Notes: Diagonal elements (values in parentheses) are the square root of the variance shared between the constructs and their measures, relative to the amount due to measurement error (AVE). Off-diagonal elements are the correlations among constructs. For discriminant validity, diagonal elements should be larger than off-diagonal elements. N.A.: Not applicable (formative construct). 
Table 3

Structural model evaluation - Influence of structural capital on innovation capability

\begin{tabular}{|c|c|c|c|c|c|c|c|c|}
\hline & & $\begin{array}{c}\text { Organi- } \\
\text { zational } \\
\text { design }\end{array}$ & $\begin{array}{c}\text { Organi- } \\
\text { zational } \\
\text { culture }\end{array}$ & HPDP & $\begin{array}{c}\text { Inno- } \\
\text { vation } \\
\text { strategy }\end{array}$ & $\begin{array}{c}\text { Techno- } \\
\text { logical } \\
\text { capital }\end{array}$ & $\begin{array}{c}\text { External } \\
\text { structure }\end{array}$ & Total R \\
\hline \multirow{2}{*}{$\begin{array}{c}\text { New idea } \\
\text { generation }\end{array}$} & Path & 0.169 & 0.122 & $0.207 *$ & $0.337^{* * *}$ & 0.061 & $0.187 *$ & \\
\cline { 2 - 10 } & Correlation & 0.599 & 0.587 & 0.607 & 0.706 & 0.453 & 0.513 & \\
\cline { 2 - 9 } & Contr. to R & $10.12 \%$ & $7.16 \%$ & $12.56 \%$ & $23.79 \%$ & $2.76 \%$ & $9.59 \%$ & $66.00 \%$ \\
\hline \multirow{2}{*}{$\begin{array}{c}\text { Innovation } \\
\text { project } \\
\text { manage- } \\
\text { ment }\end{array}$} & Path & 0.103 & $-0.207 *$ & $0.230^{*}$ & $0.476^{* * *}$ & $0.222^{* *}$ & $0.184 *$ & \\
\cline { 2 - 9 } & Correlation & 0.559 & 0.381 & 0.543 & 0.698 & 0.548 & 0.477 & \\
\hline
\end{tabular}

Notes: $\quad$ HPDP: Hiring and professional development policies. ${ }^{* * *} \mathrm{p}<0.001,{ }^{*} \mathrm{p}<0.01,{ }^{*} \mathrm{p}<0.05$ (based on $\mathrm{t}_{499}$, one-tailed test).

Table 4

Structural model evaluation - Influence of innovation capability dimensions on company performance

\begin{tabular}{|c|c|c|c|c|}
\hline & & $\begin{array}{c}\text { New idea } \\
\text { generation }\end{array}$ & $\begin{array}{c}\text { Innovation project } \\
\text { management }\end{array}$ & \multirow{2}{*}{ Total R ${ }^{2}$} \\
\hline \multirow{3}{*}{ Company performance } & Path & 0.257 & $0.483 * * *$ & \multirow{2}{*}{} \\
\cline { 2 - 5 } & Correlation & 0.566 & 0.647 & \\
\cline { 2 - 5 } & Contr. to $\mathrm{R}^{2}$ & $14.55 \%$ & $31.25 \%$ & $45.80 \%$ \\
\hline
\end{tabular}

Notes: $* * * \mathrm{p}<0.001, * * \mathrm{p}<0.01,{ }^{*} \mathrm{p}<0.05$ (based on $\mathrm{t}_{499}$, one-tailed test).

\section{CONCLUSIONS AND PRACTICAL IMPLICATIONS}

To bring this paper to a close, it can be concluded that intellectual capital is a key issue in order to promote innovation capability. In particular, structural capital proves to be extremely relevant when it comes to reinforcing the innovation capability of technologybased Colombian firms. More precisely, innovation strategy, hiring and professional development policies, and external structure are the most relevant enablers both of new idea generation and of innovation project management.

Conversely, ICT infrastructure is only relevant for the management of innovation projects. Thus, it seems that technology-based Colombian firms do not take advantage of the possibilities offered by ICT systems as a source of new ideas that could enhance their innovation capability. Perhaps, investments in this domain focus more on facilitating internal project management than on facilitating access to external sources of knowledge, and cooperation and interaction with external agents.

More surprisingly, having an organizational culture that fosters experimentation and knowledge sharing has a negative effect on innovation project management, and is not 
relevant enough for the promotion of new ideas. These results contradict theoretical assumptions about this issue. Perhaps, specific features of Colombian culture could explain this paradox.

Hofstede (1983) analyzed different cultural dimensions of 50 countries around the world. In the case of Colombia, it is noteworthy that uncertainty avoidance scored very high. This means that propensity towards risk assumption is very low. The feeling of uncertainty generates anxiety (a negative emotion) and, thus, people try to avoid attitudes and behavior that could increase this anxiety. This specific feature of Colombian culture could explain why a very open organizational culture that fosters experimentation may not promote creativity and effective project management. The creation of a context that enables experimentation implies an important degree of uncertainty which, in the case of Colombian firms, could contribute towards increasing people's anxiety. In such a state, people may not be able to develop new ideas or perform innovation projects effectively.

Another Colombian cultural feature highlighted in Hofstede's study is the low degree of individualism. In Hofstede's view, individualism shows the relative importance awarded to job aspects such as personal time, freedom and challenge, and the relative unimportance awarded to training, use of skills, physical conditions and benefits. This feature stresses goals in which the individual is an active agent versus those in which he or she is dependent on the organization (being trained, skills being used, working conditions, and benefits being provided). A low individualistic culture means that people are not active agents within the organization, but that they are very dependent on it. Perhaps, for this reason, a culture that fosters experimentation (and, therefore, the creation of a free organizational context where people have the opportunity to develop individual initiative) is counterproductive. Once more, this freedom can generate anxiety and hinder the development of new ideas as well as good project performance. When people are too dependent on the organization, they need very well established rules about what to do and how to do it.

As far as the relationship between first-level innovation capacities and company performance is concerned, only the second first-level innovation capacity (i.e. innovation project management) has a significant and positive influence on firm performance. Hence, it can be concluded that although generating new ideas is a necessary pre-condition for innovating, effective setting in motion of innovation projects is the key to transforming innovation into profits. In other words, the fact of having good ideas is not enough to obtain economic outcomes. If ideas are not implemented successfully, it is not possible to improve company performance.

From a practical perspective, this research highlights the key aspects that managers of technology-based Colombian firms should emphasize in order to increase the innovation capability of their firms and to transform this capability into performance: setting out an explicit and organization-wide shared innovation strategy; promoting hiring and professional development policies that try to enhance knowledge sharing and innovation-related competences (in particular, recruiting professionals with innovation expertise and specific training in research - i.e. people that hold $\mathrm{PhD}$ degrees, something that is not very common in Colombia - and developing external innovation networks (i.e. cooperating with external agents).

To conclude, it has to be recognized that the research carried out has some limitations that should be borne in mind. The main limitation is that the study is a cross-sectional one. 
Innovation processes are complex and the outcomes of innovation activities are not always immediate. There is often a gap between the specific point in time when an innovation project is finished and the moment when the results of this project impact on business performance. For this reason, and in order to carry out a more accurate analysis of the influence of innovation capability on business performance, a longitudinal study would be necessary, enabling innovation processes over a period of time and their effects on company's performance to be analyzed.

\section{REFERENCES}

Allee V., 2003. The Future of Knowledge: Increasing Prosperity through Value Networks. Burlington, MA: Elsevier Butterworth Heinemann,.

Andriessen D., 2004. Making Sense of Intellectual Capital - Designing a Method for the Valuation of Intangible. Burlington, MA: Elsevier Butterworth Heinemann.

Barclay D., Higgins C. and Thompson R., 1995. The Partial Least Squares (PLS) Approach to Causal Modeling: Personal Computer Adoption and Use as an Illustration, Technological Studies (special issue on Research Methodology), No.2, 285-309.

Bessant J. and Tidd J., 2007. Innovation and entrepreneurship. Chichester, West Sussex: John Wiley \& Sons.

Bontis N., 1999. Managing organizational knowledge by diagnosing intellectual capital: framing and advancing the state of the field. International Journal of Technology Management, 18(5-7), 433-462.

Brookes N.J., Morton S.C., Grossman S., Joesbury P. and Varnes D., 2007. Analyzing social capital to improve product development team performance: action-research investigation in the aerospace industry with TRW and GKN. IEEE Transactions on Engineering Management, 54(4), 814-830.

CIC, 2003. Intellectus Model: Measurement and Management of Intellectual Capital. Intellectus Document, No.5, Autonomous University of Madrid, Madrid.

Crossan, M., 2010. "A Multi-Dimensional Framework of Organizational Innovation: A Systematic Review of the Literature", Journal of Management Studies, 46 (6), 11541191.

Chin W.W. and Frye T., 2003.PLS-Graph Version 3.00, Build 1017, University of Houston, Texas.

Dalkir K., 2005. Knowledge Management in Theory and Practice. Burlington, MA: Elsevier.

Davila, T., Epstein, M., and Shelton, R., 2013. Making Innovation Work: how to manage it, measure it, and profit from it, Upper Saddle River, New Jersey: Pearson.

Drucker P., 1988. The coming of the new organization. Harvard Business Review, JanuaryFebruary, 45-53.

Edvinsson L. and Richtner A., 1999. Words of value - giving words to IC. Skandia, Sweden.

Eisenhardt K.M. and Martin J.A., 2000. Dynamic capabilities: what are they? Strategic Management Journal, 21(10-11), 1105-1121.

European Commission, 2006. RICARDIS: reporting intellectual capital to augment research, development and innovation in SMEs, Brussels.

Fischer M.M., 2001. Innovation, knowledge creation and systems of innovation. The Annals of Regional Science, 35(2), 199-216. 
Friedman V.J., Lipshitz R. and Overmeer W., 2003. Creating Conditions for Organizational Learning. in Dierkes, M., Berthoin, A., Child J. and Nonaka, I. (Eds), Handbook of Organizational Learning \& Knowledge. New York: Oxford University Press, 757-774.

Hofstede G., 1983. National cultures in four dimensions: A research-based theory of cultural differences among nations. International Studies of Management and Organization, 12(1-2), 46-74.

Ichijo K., 2007. Enabling Knowledge-Based Competence of a Corporation. In Ichijo, K. and Nonaka, I. (Eds). Knowledge Creation and Management: New Challenges for Managers. New York: Oxford University Press, 83-96.

Kalla H.K., 2005. Integrated internal communications: a multidisciplinary perspective. Corporate Communications: An International Journal, 10(4), 302-314.

Kianto A., 2007. What do we really mean by the dynamic dimension of intellectual capital?. International Journal of Learning and Intellectual Capital, 4(4), 342-356.

Kianto, A., 2008. "Development and validation of a survey instrument for measuring organizational renewal capability", International Journal of Technology Management, 42 (1-2), 69-88.

Kianto, A., Hurmelinna-Laukkanen, P., and Ritala, P., 2010. "Intellectual Capital in service- and product- oriented companies", Journal of Intellectual Capital, 11(3), 305325.

Leiponen A., 2006. Managing knowledge for innovation: the case of business-to-business services. The Journal of Product Innovation Management, 23(3), 238-258.

López, P., Martín, G., Navas, J.E., and Delgado, M., 2010. Intellectual Capital and Technological Innovation: Knowledge-Based Theory and Practice, Hershey (PA): IGI Global.

Lundvall B.A. and Nielsen P., 2007. Knowledge management and innovation performance. International Journal of Manpower, 28(3-4), 207-223.

Marr B., 2006. Strategic performance management - Leveraging and measuring your intangible value drivers. Oxford: Butterworth-Heinemann.

Martins E.C., 2000. The influence of organizational culture on creativity and innovation in a university library, MInf Dissertation, University of South Africa, Pretoria, South Africa.

Maznevski M. and Athanassiou N., 2007. Bringing the Outside in: Learning and Knowledge Management Through External Networks. In Ichijo K. and Nonaka I. (Eds), Knowledge Creation and Management: New Challenges for Managers. New York: Oxford University Press, 69-82.

Meritum Project, 2002. Guidelines for managing and reporting on intangibles. Madrid: Fundación Airtel Móvil..

Menor L.J., Kristal M.M. and Rosenzweig E.D., 2007. Examining the influence of operational intellectual capital on capabilities and performance. Manufacturing \& Service Operations Management, 9(4), 559-578.

Nahapiet J. and Ghoshal S., 1998. Social capital, intellectual capital, and the organizational advantage. Academy of Management Review, 23(2), 242-266.

Nenonen S., 2004. Analyzing the intangible benefits of work space. Facilities, 22(9-10), 233-239.

Nonaka I., 1991. The Knowledge-Creating Company. Harvard Business Review, 69(6), 96-104. 
Nonaka I. and Takeuchi H,. 1995. The Knowledge-Creating Company. New York: Oxford University Press..

Nonaka I., Reinmoeller P. and Senoo D., 1998. The Art of Knowledge: Systems to Capitalize on Market Knowledge. European Management Journal, 16(6), 673-684.

Nonaka I., Schamer O., and Toyama R. (2001) "Building ba to enhance knowledge creation and innovation at large firms", [on line], www.dialogonleadership.org/Nonaka_et_al.html.

Nonaka I., Toyama R. and Byosière P., 2003. A Theory of Organizational Knowledge Creation: Understanding the Dynamic Process of Creating Knowledge. In Dierkes M., Berthoin A., Child J. and Nonaka I. (Eds), Handbook of Organizational Learning \& Knowledge. New York: Oxford University Press, 491-517.

Nonaka I., von Krogh G. and Voelpel S., 2006. Organizational Knowledge Creation Theory: Evolutionary Paths and Future Advances. Organization Studies, 27(8), 1179-1208.

Plessis M., 2007. The role of knowledge management in innovation. Journal of Knowledge Management, 11(49), 20-29.

Roos, G. and Pike, S., 2009. "An Intellectual Capital view of business model innovation”, In Bounfour, A. (Ed.), Organizational Capital: Modelling, measuring, and contextualising, New York: Routledge, 40-62.

Shapiro C. and Varian H., 1998. Information Rules: A Strategic Guide to the Network Economy. Boston, MA: Harvard Business School Press.

Stewart T.A., 1997. Intellectual capital: the new wealth of organization. New York: Doubleday/Currency..

Subramaniam M. and Youndt M.A., 2005. The influence of intellectual capital on the types of innovative capabilities. Academy of Management Journal, 48(3), 450-463.

Sveiby K.E., 1997. The New Organizational Wealth: Managing and Measuring Knowledge-Based Assets. San Francisco, CAQ: Berrett-Koehler Publishers..

Teece D.J., 2007. Explicating dynamic capabilities: The nature and microfoundations of (sustainable) enterprise performance. Strategic Management Journal, 28(13), 1319-1350.

Teece D.J., 2009. The nature and microfoundations of (sustainable) enterprise performance. In Teece D.J. (Ed.), Dynamic capabilities \& strategic management - Organizing for innovation and growth. New York: Oxford University Press, 3-64.

Thompson V.A., 1965. Bureaucracy and innovation. Administrative Science Quarterly, $10(1), 1-20$.

Van de Ven A. H., 1986. Central problems in the management of innovation. Management Science, 32(5), 590-607.

Wiig K., 2004. People-Focused Knowledge Management. Oxford: Elsevier..

Wold H., 1985. Partial least squares. In Kotz S. and Johnson N.L. (Eds.), Encyclopedia of Statistical Sciences. New York: Wiley, 581-591.

Wu S.H., Lin L.Y. and Hsu M.Y., 2007. Intellectual capital, dynamic capabilities and innovative performance of organizations. International Journal of Technology Management, 39(3-4), 279-296.

Yang, C. and Lin, C., 2009. "Does Intellectual Capital mediate the relationship between HRM and organizational performance?, Perspective of a healthcare industry in Taiwan”, International Journal of Human Resource Management, 20 (9), 1965-1984.

Youndt M.A., Subramaniam M. and Snell, S.A., 2004. Intellectual capital profiles: an examination of investments and returns. Journal of Management Studies, 41(2), 335-362. 